\title{
Always one step ahead: How pathogenic bacteria use the type III secretion system to manipulate the intestinal mucosal immune system
}

\author{
Anna Vossenkämper ${ }^{*}$, Thomas T MacDonald and Olivier Marchès
}

\begin{abstract}
The intestinal immune system and the epithelium are the first line of defense in the gut. Constantly exposed to microorganisms from the environment, the gut has complex defense mechanisms to prevent infections, as well as regulatory pathways to tolerate commensal bacteria and food antigens. Intestinal pathogens have developed strategies to regulate intestinal immunity and inflammation in order to establish or prolong infection. The organisms that employ a type III secretion system use a molecular syringe to deliver effector proteins into the cytoplasm of host cells. These effectors target the host cell cytoskeleton, cell organelles and signaling pathways. This review addresses the multiple mechanisms by which the type III secretion system targets the intestinal immune response, with a special focus on pathogenic E. coli.
\end{abstract}

Keywords: gut-associated lymphoid tissue type 3 secretion system, EPEC, Shigella

\section{Review}

\section{The gut-associated lymphoid tissue}

The intestinal lumen is exposed to the environment and therefore in continuous contact with harmless as well as pathogenic microorganisms. Thus, it is not surprising that the gut is the biggest lymphoid organ in the body and contains about $70 \%$ of the body's immune cells [1-3]. The gut-associated lymphoid tissue (GALT) uses a range of mechanisms to protect the host from pathogens, while it at the same time tolerates commensal microorganisms. Furthermore, the GALT needs to prevent the invasion of harmful agents without affecting the absorption of nutrients from the lumen.

GALT is comprised of the appendix, single lymphoid follicles (Figure 1) in the small and large intestine, and the Peyer's patches (PP). The latter are clusters of follicles and have a distinct architecture with germinal centers containing B cells and follicular dendritic cells (DCs) which are surrounded by areas with $\mathrm{T}$ cells and macrophages [2]. PP are covered by specialized microfolded epithelial cells, the M-cells, which make up the

\footnotetext{
* Correspondence: a.vossenkaemper@qmul.ac.uk
Centre for Immunology and Infectious Disease, Blizard Institute of Cell and

* Correspondence: a.vossenkaemper@qmul.ac.uk
Centre for Immunology and Infectious Disease, Blizard Institute of Cell and Molecular Science, Barts and the London School of Medicine and Dentistry, London, UK
}

(c) 2011 Vossenkämper et al; licensee BioMed Central Ltd. This is an Open Access article distributed under the terms of the Creative Commons Attribution License (http://creativecommons.org/licenses/by/2.0), which permits unrestricted use, distribution, and reproduction in any medium, provided the original work is properly cited. follicle-associated epithelium (FAE). This epithelium and the immune cells of the GALT [4]. PP have no afferent lymph vessels and antigens are received directly from the intestinal lumen. After the uptake of luminal material by endocytosis and phagocytosis, the M-cells deliver antigens and microbes to antigen-presenting cells in the subepithelial dome of the PP, which subsequently present them to PP T cells [2]. PP DCs also directly sample bacteria from the intestinal lumen by sending protrusions through the epithelial layer without disrupting epithelial integrity [5]. Therefore, follicles and PP are an inductive site where microorganisms are sensed and the appropriate immune response is initiated [4]. In contrast, the lamina propria is an effector site; after activation in PP, DCs migrate to the mesenteric lymph nodes where they present antigens to $\mathrm{B}$ and $\mathrm{T}$ cells and the immune response is amplified. Via expression of homing molecules, mainly the integrin alpha4beta7 and CCR9, the lymphocytes are then able to reenter the mucosal site where they contribute to immune defense along the entire length of the intestine [6].

The gut has a wide range of strategies to fight infections. Amongst the non-specific mechanism are the mucus layer which traps microorganisms, the secretion 


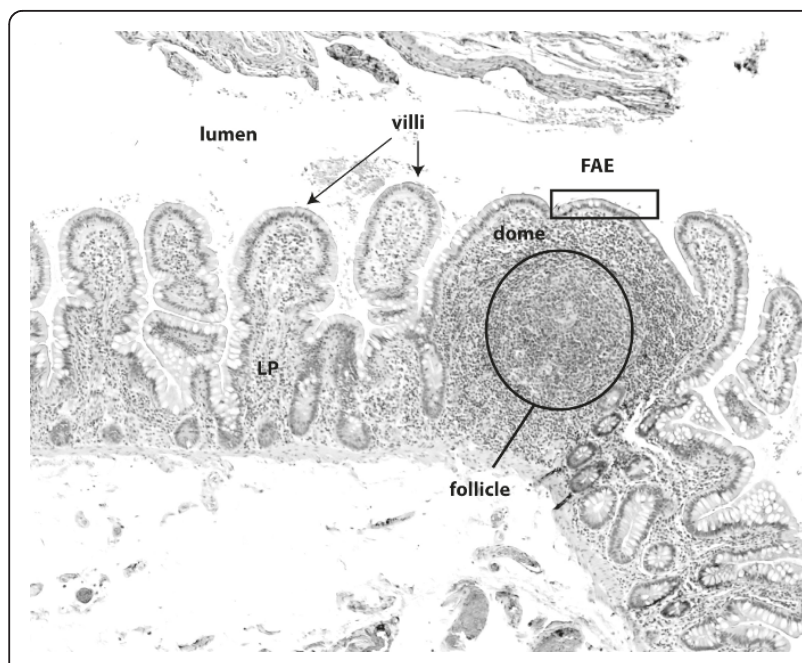

Figure 1 Follicles and PP are the inductive site for the mucosal immune response. Micrograph of a human ileal lymphoid follicle stained with hematoxylin \& eosin. The follicle is covered by M-cells which form the follicle-associated epithelium (FAE). Underneath the dome area which holds dendritic cells, is a B cell follicle, surrounded by a $T$ cell-rich zone. Adjacent to the follicle are microvilli. LP = lamina propria

of anti-microbial agents such as defensins, trefoil factors and proteases, intestinal peristalsis, and the natural microbiota which compete with pathogens for epithelial binding and nutrients [7-10]. Microorganisms are also largely prevented from epithelial attachment by secretory IgA (sIgA) which binds them in the lumen and mucus [11]. Germinal center B cells receive multiple activation and survival signals from follicular DCs in PP upon encounter with bacterial products leading to the generation of IgA secreting plasmablasts [12]. After activation and $\mathrm{T}$ cell-dependent class switching to IgA in the PP, B cells eventually migrate to the lamina propria where they reside as IgA secreting plasma cells $[13,14]$. Cellular defense mechanisms within the lamina propria are crucial in reducing and dealing with invasion of pathogens. The main cell population comprises CD4+ T lymphocytes which, depending on the cytokine milieu, respond by producing factors associated with a Th1 immune response which is crucial for the response to intracellular pathogens and stimulates phagocytosis by macrophages. A Th2 response is typically established following infection with parasites and involves production of IL-4, IL-5, IL-10, and IL-13 resulting in activation and recruitment of $B$ cells, mast cells and eosinophils [15].

The lamina propria also contains natural killer cells which are thought to mediate intestinal homeostasis by producing IL-22 and exhibit their cytotoxic functions upon activation by $\mathrm{T}$ cells $[16,17]$. IL-22 has been shown to be an important factor in the host defense against enteral bacteria, like e.g. Citrobacter rodentium, a murine pathogen which is used to study infections with enteropathogenic E. coli (EPEC) and enterohaemorrhagic E. coli (EHEC) in humans [18]. Additional studies highlighted the importance of IFNg-producing CD4+ T cells in the defense against these bacteria [19].

Another layer of defense is located in the epithelium where a large population of mainly $C D 8 \alpha \beta$ intraepithelial $\mathrm{T}$ lymphocytes resides in the basolateral area, between the epithelial cells [20]. Some studies demonstrated cytolytic activity of these $\mathrm{T}$ cells which suggest they might be involved in cancer surveillance and killing of infected cells [21].

\section{Recognition of bacteria in the intestine}

The intestinal immune system faces the constant challenge of discriminating between the commensal microbiota and pathogens. The response to the latter is usually rapid and results in the activation of innate and adaptive immune mechanisms that lead to inflammation and eradication of the pathogen, sometimes with considerable damage to the intestinal mucosa. Non-pathogenic bacteria that form the microbiota are also recognized by the GALT [22]; however, the immune response to commensals appears to be strictly controlled, and does not lead to overt inflammation. How the GALT discriminates between these two categories of microorganisms, commensals and pathogens, is complex and not fully understood. However, DCs in GALT are of paramount importance for responding to bacterial stimuli and the initiation of a tolerogenic state by promoting the expression of anti-inflammatory molecules like IL-10 and TGFbeta [23].

In the last two decades, with the discovery of toll-like receptors (TLR) and Nod-like receptors (NLR) which recognize pathogen-associated molecular patterns (PAMPs), the knowledge about the recognition of microbial structures by immune and epithelial cells has dramatically increased [24]. These receptors specifically bind ligands widely shared amongst pathogens. Wellcharacterised examples of such ligands are bacterial cell wall components such as peptidoglycans and lipoproteins (both binding to TLR2) or nucleic acid ligands such as bacterial CpG DNA which binds to TLR9 $[25,26]$. Immune recognition via pattern-recognition receptors is crucial for host defense and immune homeostasis, and dysfunction of these receptors has been shown to be associated with gut inflammatory conditions such as Crohn's disease [27]. Binding of microbial ligands to TLRs (besides TLR3) results in the activation of a pro-inflammatory MyD88-dependent pathway that leads to activation of the transcription factor NF-kappaB. Another signaling pathway that is critically involved in inflammation is the mitogen-activated protein (MAP) 
kinase-cascade. Although not activated by microbial ligands, this pathway is initiated by extracellular stimuli like pro-inflammatory cytokines or mitogens [28]. Both the NF-kappaB and MAPK pathway are activated in intestinal infections by pathogens which use type III secretion systems (T3SS) [29]. These pathways are also amongst the known targets for T3SS effectors. An overview on how these pathways are affected during intestinal infection with pathogens that employ the T3SS is discussed here, with special emphasis on EPEC and EHEC. These two pathogens, also known as attaching and effacing pathogens (A/E), are amongst the leading causes for diarrheal diseases. EPEC is a big health concern, especially for infants, in developing countries. An EPEC infection can be asymptomatic, but the classical feature of the infection is profuse watery diarrhea in combination with vomiting. EHEC is responsible for food-borne outbreaks of diarrheal diseases, with contaminated beef being the most common vehicle for infection. Certain EHEC strains (e.g. O157:H7) produce Shiga-like toxins which can cause potentially life threatening complications like the hemolytic-uremic syndrome (HUS). This disease is characterized by acute kidney failure, thrombocytopenia and hemolytic anemia and affects mostly children. The mortality of HUS is approximately $5-10 \%$ and it is therefore a medical emergency requiring intensive clinical care.

\section{Sustaining colonization by preventing bacterial detachment and death of infected cells}

Some of the most successful gram-negative pathogens use the type 3 secretion system (T3SS), a molecular syringe, to inject an arsenal of virulence effector proteins directly into the cytoplasm of the host cells. The effectors can then target and hijack various host cell functions for the benefit of the pathogen [30]. The increasing understanding of the variety of T3SS effectors and their functions has given rise to the idea that for every defense strategy used by the host, there might be antagonistic effector proteins. Recent data gained from research on the function of Shigella effectors, illustrate this hypothesis [31]. One of the protective mechanisms of the gut mucosa is the constant renewal and shedding of epithelial cells at the top of the villi in the small bowel and from the colon surface. If subjected to bacterial colonization, the enterocytes can undergo programmed cell death and detach from the extracellular matrix into the lumen, preventing the pathogen crossing the epithelium [32,33]. In vitro and in vivo data identified two Shigella effectors, IpaB and OspE, which counteract the intestinal epithelial turnover and exfoliation [34,35]. IpaB causes a cell cycle arrest of infected cells by interacting with Mad2L2, an inhibitor of the anaphase promoting complex (APC) which regulates the cell cycle [34]. In a rabbit ileal loop model, intestinal crypts infected with Shigella that express an IpaB mutant protein which is unable to interact with Mad2L2, have a higher number of progenitor cells and are less colonized than with the wild type strain. These findings suggest that IpaB, by blocking intestinal cell proliferation and renewal, prolongs Shigella colonization [34]. Shigella also injects the effector OspE into enterocytes which stabilizes the adhesion of intestinal cells to the extra-cellular matrix by targeting and modulating the function of integrin-linked kinase (ILK), a modulator of focal adhesion [35]. The interaction between OspE and ILK enhances the presence of beta1-integrin at the cell surface and prevents the disassembly of focal adhesions. An in vivo study performed in a guinea pig colon infection model showed reduced colonization and pathogenicity of OspE mutant bacteria. This study suggests that OspE enhances the infectivity of Shigella by preventing the exfoliation of infected intestinal cells [35].

Some EPEC and EHEC strains as well as the mouse pathogen Citrobacter rodentium might also use a similar strategy as they possess the effector EspO which has strong homology with Shigella's OspE $[35,36]$. The inhibition of epithelial cell detachment is an emerging theme in bacterial pathogenesis, and recent in vivo work suggests that it is a strategy shared by all bacteria that are able to bind human carcino-embryonic antigenrelated cell adhesion molecules (CEACAM), e.g. Neisseria gonorrhoeae, Neisseria meningitidis, Moraxella catarrhalis, and Haemophilus influenzae [32,37].

Interestingly, some EPEC strains produce the effector Cif which blocks the cell cycle of infected cells [38]. Cif binds Nedd8, a ubiquitin-like protein and inhibits neddylated Culling-RING ligases-induced (CLRs) ubiquitination of a variety of CLR substrates, such as the cell cycle inhibitors p21waf1 and p27kip1 [39,40]. It is thus possible that in EPEC, Cif acts like Shigella's IpaB, and also prolongs colonization of the gut mucosa by preventing epithelial cell renewal.

Other work suggests that inhibition of the epithelial renewal and exfoliation could indeed be an infective strategy of EPEC and EHEC pathogens. Shames and coworkers have demonstrated a role for the effector EspZ in reducing the death and detachment of epithelial cells infected with EPEC in vitro [41]. EspZ binds the transmembrane glycoprotein CD98 and enhance its effect on beta1-integrin signaling and cell survival via activation of focal adhesion kinase. EspZ also activates the pro-survival AKT pathway, which does not seem to rely on CD98 binding [41].

A potent pro-survival activity has also been identified for NleH1 and NleH2, two effectors produced by EPEC and EHEC. NleHs inhibits apoptosis via various stimuli 
in epithelial cells, dependent on the binding to the antiapoptotic Bax inhibitor-1 [42]. The mechanism by which $\mathrm{NleH}$ prevents cell death is independent of its kinase function and remains to be determined.

Another effector reported to be potentially involved in anti-apoptotic activity is the metalloprotease NleD which prevents JNK-mediated pro-apoptotic signaling by cleaving and inactivating JNK [43]. Apart from the effector EspZ, which is severely attenuated for virulence in the mouse model [44], an essential role for other effectors in virulence like NleHs and NleD have not been established in different animal models $[45,46]$. Although in vivo evidence is missing, these studies suggest that EPEC and EHEC use EspO, EspZ, NleH, and NleD to prevent or delay the exfoliation and apoptotic clearance of the targeted cells in the intestinal epithelium and to sustain bacterial colonization (Figure 2 and table 1).

\section{Modulation of proinflammatory signaling pathways}

The modulation of the host immune response by effectors from Shigella, Salmonella, and Yersinia is increasingly well understood. Detailed reviews on immune modulation by these pathogens have previously been

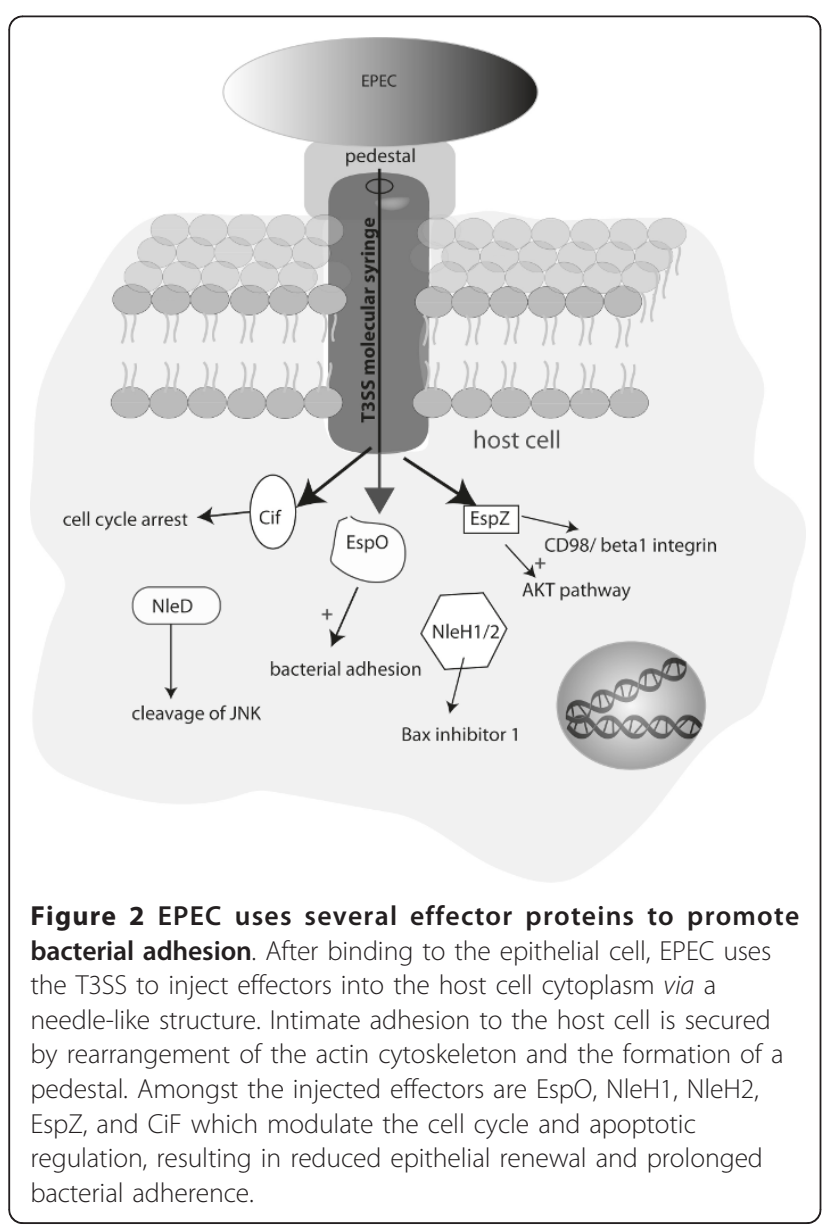

published elsewhere [30,47]. EPEC, EHEC and C. rodentium pathogens have a common set of T3SS effectors composed of seven LEE and a few non-LEE encoded effectors like NleE, NleB, and $\mathrm{NleH}$ and show diversity in the repertoire of other non-LEE encoded effectors. The reference strains EHEC 0157:H7 Sakai, EPEC O127: H6 strain E2348/69, EPEC O111:NM strain B171, and Citrobacter rodentium have a total of 50, 21, 28 and 29 full length effector genes, respectively [48]. Surprisingly, despite almost 20 years of research on the function of EPEC and EHEC effectors, manipulation of immune defenses in the gut had not been reported until recently; perhaps because as a pathogen which adheres to the surface of epithelial cells, it was not thought to come into contact with host immune cells. The described functions of effectors were mainly the modification of the host cell cytoskeleton in relation to the formation of intestinal attaching/effacing (A/E) lesions and the modification of epithelial tight-junctions in relation to the alteration of intestinal permeability observed during infection [49]. Some apparently contradictory results have been published concerning the pro-or anti-inflammatory activity of EPEC and EHEC. Earlier work demonstrated that the bacteria trigger a pro-inflammatory response $[50,51]$. However, many studies using epithelial cell lines now clearly show that whereas the bacteria induce an inflammatory response with the detection systems of the host cells, they are able to inhibit the inflammatory pathways in a T3SS-dependent manner [52,53]. By hampering the pro-inflammatory response of epithelial cells, EPEC and EHEC are likely to gain the advantage of reduced cytokine and chemokine secretion which subsequently reduces the recruitment of neutrophils into the affected site. Neutrophils are effective at killing bacteria and release a variety of anti-microbial factors; thus a reduced number and activation of these cells would prolong colonization [54]. Only very recently, anti-inflammatory activity has been demonstrated for the EPEC and EHEC effectors NleE, NleB, NleH, NleD and NleC (Figure 3 and table 1).

$\mathrm{NleH} 1$ was the first effector reported to inhibit NFkappaB in HeLa and HEK293T cell lines [55]. NleH1 and NleH2 both bind the human ribosomal protein S3 (RPS3) in the cytoplasm of infected cells. RPS3 is a nonRel NF-kappaB subunit and interacts with p65 to increase the transcription of various pro-inflammatory genes [56]. NleH1, but not NleH2, blocks the transcription of RPS3/NF-kappaB-dependent genes by preventing the nuclear translocation of RPS3 [55]. In a gnotobiotic piglet infection model, animals infected with EHEC mutated for nleH1 died more rapidly compared to piglets infected with the wild-type or an nleH2 mutant. The hypervirulent phenotype that was caused by the nleH1 mutant, seemed to be due to a pronounced 
Table 1 Effectors of EPEC/EHEC that modulate cell detachment, pro-inflammatory signaling, and phagocytosis

\begin{tabular}{|c|c|c|c|c|}
\hline Effector & $\begin{array}{l}\text { Cellular } \\
\text { targets }^{\mathrm{a}}\end{array}$ & $\begin{array}{l}\text { Biochemical activity/ } \\
\text { characteristics }^{\mathrm{b}}\end{array}$ & Phenotype & In vivo role \\
\hline \multicolumn{5}{|c|}{ Inhibition of cell detachment and modulation of cell death } \\
\hline $\begin{array}{l}\text { NleH1 } \\
\text { NleH2 }\end{array}$ & $\begin{array}{l}\text { Bax } \\
\text { inhibitor-1 } \\
(\mathrm{Bl}-1)\end{array}$ & $\begin{array}{l}\text { Binds to N-terminal amino acid 1- } \\
40 \text { of Bl-1. N-terminal aa 1-100 of } \\
\text { NleHs not required for binding to } \\
\text { Bl-1 }\end{array}$ & $\begin{array}{l}\text { Inhibition of apoptosis induced via multiple } \\
\text { stimuli }\end{array}$ & $\begin{array}{l}\text { Various roles reported in vivo. } \mathrm{NleH} \\
\text { reduces the level of apoptotic } \\
\text { colonic cells in mouse model [42] }\end{array}$ \\
\hline$\overline{E s p Z}$ & CD98 & $\begin{array}{l}\text { C-terminal amino acid domain 43- } \\
99 \text { required for CD98 binding }\end{array}$ & $\begin{array}{l}\text { Prevent cell detachment. Enhance activation of } \\
\text { pro-survival FAK and AKT pathway. Binding to } \\
\text { CD98 promotes } \beta 1 \text {-integrin activation of FAK. }\end{array}$ & $\begin{array}{l}\text { Mutant esp Z attenuated for } \\
\text { colonization and hyperplasia in mice } \\
\text { [44] }\end{array}$ \\
\hline NleD & JNKs, p38 & $\begin{array}{l}\text { Zinc metalloprotease (motif } \\
{ }_{142} \mathrm{HExxH}_{146} \text { ) }\end{array}$ & $\begin{array}{l}\text { Cleaves MAP kinases JNK and p38 in the } \\
\text { activation loop. Reduce JNK pro-apoptotic activity }\end{array}$ & $\begin{array}{l}\text { Enhance colonization in calves, no } \\
\text { role identified in mice and lamb } \\
\text { infection models }[45,46]\end{array}$ \\
\hline Cif & NEDD8 & Deamidase of NEDD8 and ubiquitin & Block cell cycle at G2/M and G1/S transitions [39] & Unknown \\
\hline $\begin{array}{l}\text { Espo/ } \\
\text { OspO }\end{array}$ & ILK (?) & $\begin{array}{l}\text { Shigella's OspE C-terminal }{ }_{68} \mathrm{~W} \\
\text { essential for activity is conserved in } \\
\text { EPEC/EHEC EspO/OpsO }\end{array}$ & Prevent cell detachment? & Unknown \\
\hline \multicolumn{5}{|c|}{ Inhibition of pro-inflammatory signaling } \\
\hline NleE & Unknown & $\begin{array}{l}\text { C-terminal }{ }_{208} \mathrm{IDSYMK}_{214} \text { motif } \\
\text { essential for activity }\end{array}$ & $\begin{array}{l}\text { Inhibits TNF } \alpha, I L-1 \beta \text { and PRRs mediated activation } \\
\text { of NF-kappaB and expression of pro-inflammatory } \\
\text { cytokines in epithelial and immune cells. Acts by } \\
\text { inhibition of I } \kappa \text { B } \alpha \text { phosphorylation blocking p } 65 \\
\text { nuclear translocation }\end{array}$ & $\begin{array}{l}\text { Slight role in colonization and } \\
\text { persistence reported }[45,60]\end{array}$ \\
\hline$\overline{\mathrm{NleC}}$ & $\begin{array}{l}\mathrm{p} 65, \mathrm{p} 50 \\
\mathrm{c}-\mathrm{Rel}, \mathrm{I} \mathrm{B} \alpha\end{array}$ & $\begin{array}{l}\text { Zinc metalloprotease (motif } \\
1{ }_{183} \mathrm{HExxH}_{187} \text { ) } \\
\mathrm{N} \text {-terminal domain aa } 33-64 \\
\text { required for p65 and p50 binding }\end{array}$ & $\begin{array}{l}\text { Cleaves p65 and p50 to inhibit NF-kappaB } \\
\text { activation. Cleavage of c-Rel and I } \kappa \mathrm{B} \alpha \text { also } \\
\text { reported. }\end{array}$ & $\begin{array}{l}\text { No role identified in mice and lamb } \\
\text { infection model }[45,46]\end{array}$ \\
\hline NleB & Unknown & Unknown & Inhibit TNF $\alpha$-mediated NF-kappaB activation & $\begin{array}{l}\text { Required for colonization and } \\
\text { disease in mouse model }[45,60]\end{array}$ \\
\hline NleH1 & $\begin{array}{l}\text { Ribosomal } \\
\text { protein S3 } \\
\text { (RPS3) }\end{array}$ & $\begin{array}{l}\text { Activity in N-terminal } 139 \text { amino } \\
\text { acid (N40 and K45 required for } \\
\text { RPS3 inhibition) }\end{array}$ & $\begin{array}{l}\text { Prevent RPS3 nuclear translocation and } \\
\text { expression of RPS3-NF-kappaB dependent pro- } \\
\text { inflammatory genes }\end{array}$ & $\begin{array}{l}\text { NleH1 EHEC mutant hypervirulent in } \\
\text { piglet infection model [55] }\end{array}$ \\
\hline $\begin{array}{l}\text { NleH1 } \\
\text { and } \\
\text { NleH2 }\end{array}$ & Unknown & Serine-threonine kinase motif & Prevent $I \kappa B \alpha$ ubiquitination and degradation & $\begin{array}{l}\text { Required for colonization and } \\
\text { reduction of inflammation in EPEC } \\
\text { mouse model [58] }\end{array}$ \\
\hline NleD & JNK, p38 & $\begin{array}{l}\text { Zinc metalloprotease (motif } \\
{ }_{142} \mathrm{HExxH}_{146} \text { ) }\end{array}$ & $\begin{array}{l}\text { Cleaves MAP kinases JNK and } \mathrm{p} 38 \text { in the } \\
\text { activation loop. Contributes to overall bacterial } \\
\text { mediated inhibition of IL-8 in vitro. }\end{array}$ & $\begin{array}{l}\text { Mutant not attenuated in mice, } \\
\text { calve and lamb models }[45,46] \text {. Role } \\
\text { in colonization in STM screen in } \\
\text { calves }\end{array}$ \\
\hline \multicolumn{5}{|c|}{ Inhibition of phagocytosis } \\
\hline EspF & Unknown & $\begin{array}{l}\text { N-term } 101 \text { amino acid for anti- } \\
\text { phagocytic activity }\end{array}$ & $\begin{array}{l}\text { Prevents PI3K-dependent phagocytosis of } \\
\text { bacteria; } \\
\text { Reduces uptake of EPEC bacteria in in vitro } \mathrm{M} \text { cell } \\
\text { model }\end{array}$ & $\begin{array}{l}\text { EspF mutant attenuated in mice } \\
\text { model. Specific role of anti- } \\
\text { phagocytic activity unknown }[77,78]\end{array}$ \\
\hline EspB & $\begin{array}{l}\text { Myosin } \\
\text { proteins }\end{array}$ & $\begin{array}{l}\text { Domain from amino acid } 159-218 \\
\text { essential for myosin binding }\end{array}$ & $\begin{array}{l}\text { Prevents bacterial phagocytosis via inhibition of } \\
\text { myosin-actin interaction }\end{array}$ & $\begin{array}{l}\text { Citrobacter expressing EspB mutated } \\
\text { for myosin binding are attenuated } \\
\text { in mouse model [74] }\end{array}$ \\
\hline EspJ & Unknown & Unknown & Blocks FcyR and CR3-opsonophagocytosis & $\begin{array}{l}\text { Role in bacterial clearance } \\
\text { reported in mouse model [75] }\end{array}$ \\
\hline EspH & RhoGEFs & $\begin{array}{l}\text { Binds to DH-PH domain of RhoGEFs } \\
\text { and inhibits RhoGTPase signalling }\end{array}$ & $\begin{array}{l}\text { Attenuates bacteria phagocytosis and FcyR- } \\
\text { mediated phagocytosis }\end{array}$ & $\begin{array}{l}\text { EspH mutant not or slightly } \\
\text { attenuated for colonization in mice } \\
\text { and rabbit model [44] }\end{array}$ \\
\hline
\end{tabular}

\footnotetext{
${ }^{a}$ In relation to phenotype described; ${ }^{b}$ Motif or biochemical activity required for phenotype described
}

inflammatory response [55]. NleHs are auto-phosphorylated serine threonine kinases and share homology with the Shigella effector OspG which is known to inhibit NF-kappaB [57]. The RPS3-mediated inhibition of inflammation differs from OspG activity and is independent of the kinase function [55]. It was recently demonstrated that both $\mathrm{NleH} 1$ and NleH2 could inhibit NF-kappaB in a kinase-dependent manner [58]. NleH1 and NleH2 prevent TNFalpha-mediated NF-kappaB activation by inhibiting IkappaBalpha ubiquitination and 


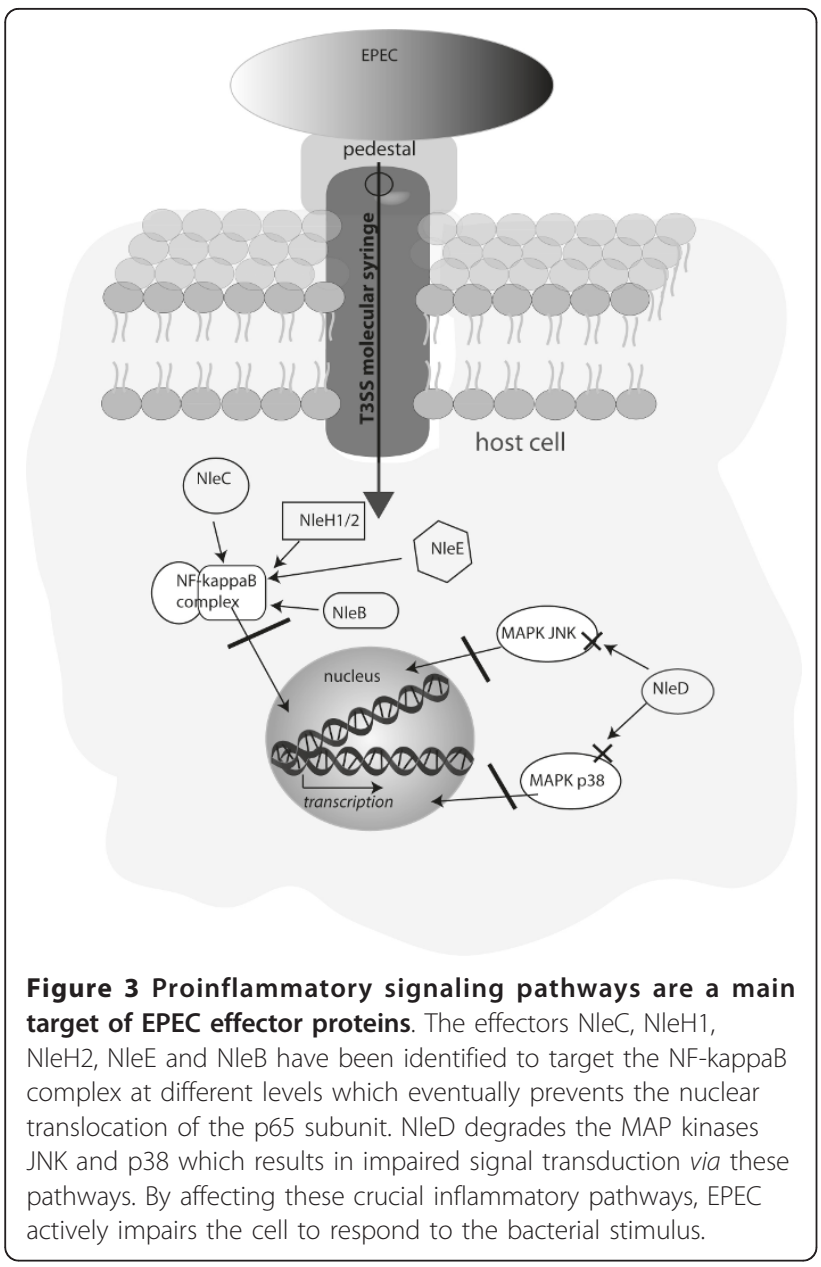

degradation and this activity is dependent on lysine residues present in the kinase domain of both effectors [58]. Streptomycin treated mice infected with EPEC mutated for NleH1 and NleH2 were less colonized, showed higher number of neutrophil infiltration and higher serum level of KC (the mice homologue of IL-8) compared to mice infected with the wild-type, suggesting that $\mathrm{NleH}$ promotes colonization and is required for the modulation of the host inflammatory response [58].

$\mathrm{NleB}$ is encoded on the same pathogenicity island as NleE in EPEC and EHEC O157 strains, on the integrative element IE6 and the O-island 122, respectively [59]. Presence of the O Island 122 (OI122) is associated with EHEC outbreaks and the hemolytic uremic syndrome, a severe complication of an EHEC infection [60]. Citrobacter rodentium strains that have a mutated NleB effector, show an impaired ability to colonise the murine intestine and fail to induce intestinal crypt hyperplasia in the mouse model of infection [45,60]. NleB specifically inhibits NF-kappaB in response to TNFalpha stimulation in epithelial cell lines [61]. NleB's mode of action has yet to be identified but is supposed to act upstream of the IKK complex in the TNFalpha pathway, as NleB is unable to prevent NF-kappaB activation in cells following stimulation with IL-1beta or by bacterial PAMPs [61].

Four independent studies have reported that $\mathrm{NleC}$ is a metalloprotease that degrades the p65 NF-kappaB subunit in epithelial cell lines and contributes to the overall anti-inflammatory activity of both EPEC and EHEC strains [43,62-64]. NleC carries the zinc metalloprotease motif 183 HEIIH187 which is essential for the proteolytic activity on $\mathrm{p} 65$. In addition to $\mathrm{p} 65, \mathrm{NleC}$ also cleaves the NF-kappaB p50 subunit and IkappaBalpha $[62,63]$. Mülhen and co-workers showed that the N-terminal motif between amino acid 33 and 64 is required for binding to p65 and p50 [62].

EPEC and EHEC produce another zinc metalloprotease, NleD, which specifically degrades MAPK JNK and p38 and contributes to the overall inhibition of IL-8 chemokine secretion by infected cells [43]. Mutation of the zinc metalloprotease motif in NleD, HEXXH, abolishes JNK cleavage.

Colonization and pathogenicity of bacteria mutated for $\mathrm{NleC}$ or NleD was not impaired in mice, lamb and calve infection models. Therefore the importance of each of the anti-inflammatory effectors remains to be identified [44-46]. As suggested by in vitro data which show that full IL-8 inhibition was dependent on the conjugated activity of mainly NleE and $\mathrm{NleC}$, but also NleB and $\mathrm{NleD}$, it is likely that the mutation of any of the effectors is compensated in vivo by the activity of the other $[43,63,64]$. It would be of interest to test the in vivo pathogenicity of a strain deleted for all effectors targeting NF-kappaB to assess the importance of the antiinflammatory activity for bacterial colonization and persistence.

NleE is a T3SS effector conserved among EPEC, EHEC and Citrobacter rodentium strains. NleE is homologous to OspZ which is present in Shigella spp strains [65]. Different roles for colonization and persistence have been reported for NleE in Citrobacter rodentium mice models of infection $[45,66]$. Proteomic analysis of cell free Citrobacter rodentium secretion profile indicated that NleE, along with EspF and Tir, is the highest secreted effector, suggesting it plays a key role in virulence [67]. Indeed, NleE was shown to be a potent inhibitor of NF-kappaB which prevents nuclear p65 translocation in epithelial cells in response to TNFalpha and IL-1beta $[61,68]$. The mechanism by NleE blocks NF-kappaB signaling is not known. It was, however, suggested that NleE targets the IKK complex and prevents the phosphorylation of IKKbeta [68]. Although so far no functional domain was found that could explain NleE's mode of action, an analysis of the $n l e E$ sequence identified a motif 206IDSYMK214 of unknown function 
which is not sufficient but essential for NleE's antiinflammatory activity [61].

While other research on NleE showed its inhibiting effect on NF-kappaB signaling in epithelial cells, our group provided evidence that NleE inhibits the expression and production of pro-inflammatory cytokines IL-8, TNFalpha, and IL-6 in human DCs which was due to impaired NF-kappaB p65 nuclear translocation [69]. NleE injected by EPEC was shown to drastically reduce the production of these cytokines in human monocytederived DCs as well as PP DCs in vitro. We further showed that EPEC injects its effectors into DCs that reach through an epithelial layer in a transwell system. These results suggest that EPEC can impair NF-kappaB signaling not only in epithelial cells, but also hampers the inflammatory response in the gut by injecting into PP DCs that sample the bacteria from the lumen. Certain EPEC strains target the FAE early on in infection [70]. The fact that EPEC can impair signaling in PP DCs when they encounter them at the FAE might explain this phenomenon.

\section{Preventing phagocytosis}

Phagocytosis is a receptor-mediated process and occurs in two different ways: via the direct binding of the particle to specific receptors at the surface of the phagocyte or via earlier opsonisation of the particle by IgG or the C3bi complement fragment [71]. IgG and C3bi subsequently bind to the FcgammaR or Complement receptor 3 (CR3), respectively, at the surface of the cell. EPEC inhibits phagocytosis in infected macrophages [72]. Furthermore, EPEC blocks both the opsonin-dependent and independent phagocytic pathways in vitro by injecting the four T3SS effectors EspF, EspB, EspJ, and EspH.

EspF from both EPEC and EHEC prevents phagocytosis by macrophages and the uptake by $\mathrm{M}$ cells in in vitro models (table 1) [73-77]. EspF is a multifunctional effector implicated in various others aspect of pathogenesis. Amongst them are the alteration of the intestinal epithelial tight-junctions, the effacement of the brush border microvilli, mitochondrial-dependant apoptosis, the nucleolar disruption and the targeting of various cellular proteins like the neuronal Wiskott-Aldrich syndrome protein (N-WASP), cytokeratin 18, anti-apoptotic Abcf2 or sorting nexin $9(\mathrm{Snx} 9)$, a protein involved in vesicles trafficking [78]. The mechanism by which EspF prevents phagocytosis is still unknown and a study by Quitard and coworkers showing that the N-terminal 101 amino acid domain of EspF is essential suggests that the binding to proteins like N-WASP, actin or SNX9 are not required to prevent the uptake by macrophages [78]. Contradictory to its anti-phagocytic activity, a role for EspF in promoting enterocyte invasion has recently been described and was shown to depend on the interaction between EspF and SNX9 [79]. EspJ from EPEC and EHEC does not block phagocytosis of nonopsonized bacteria but prevents both the FcgammaR and CR3 opsonin-dependant phagocytosis of particles by macrophages or FcgammaR- or CR3-transfected cells [75]. The mechanism by which EspJ blocks opsonophagocytosis remains to be identified. EspB hampers phagocytosis by binding and inhibiting host myosin functions which are required for phagocytosis of non-opsonized bacteria [74]. EspH is the only effector reported to inhibit both opsono- and non-opsonophagocytosis. It binds to the DH-PH domain of several Rho GTPase exchange factors (RhoGEF), preventing activation of Rho GTPases and inducing a general inhibition of actin polymerisation which would explain the inhibition of phagocytosis [73]. The identification of anti-phagocytic activity of so far four effectors translocated by EPEC and EHEC suggest their importance for the in vivo pathogenesis. A recent paper reported that the effector EspG targets ARF6 GTPases which results in the reprogramming of endomembrane trafficking [80]. This finding raises the question whether EspG also plays a role in the general antiphagocytic activity as ARF6 is essential for FcgammaRmediated phagocytosis [81].

Although EPEC is a non-invasive pathogen, its mucosal uptake has been reported in various in vitro and in vivo studies [82]. The relevance of EPEC invasion for pathogenesis is not known but might play a role in persistence of the pathogen inside the host. Since EPEC and EHEC mediate disease from their luminal position, one might wonder how relevant the interaction of the bacteria with professional phagocytic cells is during infection. EPEC is known to target the FAE in the gut [70], so the inhibition of its own uptake, which was observed under in vitro conditions [76], could reflect the inhibition of its $\mathrm{M}$ cells transcytosis resulting in immune evasion. On the other hand, in vivo studies with Citrobacter rodentium in mice have shown that the activity of neutrophils were necessary to clear the infection, suggesting that at some point during the infection the bacteria interact with phagocytic cells [83].

\section{Conclusion}

Pathogenic bacteria have evolved alongside their hosts, developing sophisticated mechanisms and effector proteins to manipulate the host cells on multiple levels. Not only do bacteria which use the T3SS secure their attachment to epithelial cells by altering the cytoskeleton, they also actively prevent phagocytosis in the gut and impair the immune response by interfering with pro-inflammatory signaling pathways. While these modulatory strategies might not be clinically detrimental to infected individuals, the bacteria gain the advantage of facilitated and prolonged colonization in the gut. The 
variety of immuno-modulatory effectors in T3SSemploying pathogens might also explain why e.g. EPEC shows a tropism for the GALT, since this is the site where the bacteria encounter DCs which they modulate to hamper the initiation of the intestinal immune response.

\section{Abbreviations}

DC: dendritic cell; EHEC: enterohaemorrhagic E. coli; EPEC: enteropathogenic Escherichia coli; FAE: follicle-associated epithelium; GALT: gut-associated lymphoid tissue; PP: Peyer's patch; T3SS: type-3 secretion system.

\section{Acknowledgements and Funding}

A.V. is funded by the Medical Research Council, UK

\section{Authors' contributions}

All authors wrote, read and approved the final manuscript.

\section{Competing interests}

The authors declare that they have no competing interests.

Received: 15 March 2011 Accepted: 3 May 2011 Published: 3 May 2011

\section{References}

1. Castro GA, Arntzen CJ: Immunophysiology of the gut: a research frontie for integrative studies of the common mucosal immune system. Am J Physiol 1993, 265:G599-610.

2. Jung C, Hugot JP, Barreau F: Peyer's Patches: The Immune Sensors of the Intestine. Int J Inflam 2010, 2010:823710.

3. MacDonald T: The gut is still the biggest lymphoid organ in the body. Mucosal Immunology 2008, 1:246-247.

4. Neutra MR, Mantis NJ, Kraehenbuhl JP: Collaboration of epithelial cells with organized mucosal lymphoid tissues. Nat Immunol 2001, 2:1004-1009.

5. Rescigno M, Urbano M, Valzasina B, Francolini M, Rotta G, Bonasio R, Granucci F, Kraehenbuhl JP, Ricciardi-Castagnoli P: Dendritic cells express tight junction proteins and penetrate gut epithelial monolayers to sample bacteria. Nat Immunol 2001, 2:361-367.

6. Gorfu G, Rivera-Nieves J, Ley K: Role of beta7 integrins in intestina lymphocyte homing and retention. Curr Mol Med 2009, 9:836-850.

7. Cunliffe RN, Mahida YR: Expression and regulation of antimicrobial peptides in the gastrointestinal tract. J Leukoc Biol 2004, 75:49-58.

8. Plaut AG: Trefoil peptides in the defense of the gastrointestinal tract. $N$ Engl J Med 1997, 336:506-507.

9. Kim YS, Ho SB: Intestinal goblet cells and mucins in health and disease: recent insights and progress. Curr Gastroenterol Rep 2010, 12:319-330.

10. Cerf-Bensussan N, Gaboriau-Routhiau V: The immune system and the gut microbiota: friends or foes? Nat Rev Immunol 2010, 10:735-744.

11. Macpherson AJ, Hunziker L, McCoy K, Lamarre A: IgA responses in the intestinal mucosa against pathogenic and non-pathogenic microorganisms. Microbes Infect 2001, 3:1021-1035.

12. Suzuki K, Maruya M, Kawamoto S, Sitnik K, Kitamura H, Agace WW, Fagarasan S: The sensing of environmental stimuli by follicular dendritic cells promotes immunoglobulin A generation in the gut. Immunity 2010, 33:71-83.

13. Spencer J, Barone F, Dunn-Walters D: Generation of Immunoglobulin diversity in human gut-associated lymphoid tissue. Semin Immunol 2009, 21:139-146.

14. Macpherson AJ, McCoy KD, Johansen FE, Brandtzaeg P: The immune geography of IgA induction and function. Mucosal Immunol 2008, 1:11-22.

15. Maizels RM, Yazdanbakhsh M: Immune regulation by helminth parasites: cellular and molecular mechanisms. Nat Rev Immunol 2003, 3:733-744.

16. Cella M, Fuchs A, Vermi W, Facchetti F, Otero K, Lennerz JK, Doherty JM, Mills JC, Colonna M: A human natural killer cell subset provides an innate source of IL-22 for mucosal immunity. Nature 2009, 457:722-725.

17. Takayama T, Kamada N, Chinen H, Okamoto S, Kitazume MT, Chang J, Matuzaki Y, Suzuki S, Sugita A, Koganei K, Hisamatsu T, Kanai T, Hibi T: Imbalance of NKp44(+)NKp46(-) and NKp44(-)NKp46(+) natural killer cells in the intestinal mucosa of patients with Crohn's disease. Gastroenterology 2010, 139:882-892, 892 e881-883.

18. Satoh-Takayama N, Vosshenrich CA, Lesjean-Pottier S, Sawa S, Lochner M, Rattis F, Mention JJ, Thiam K, Cerf-Bensussan N, Mandelboim O, Eberl G, D Santo JP: Microbial flora drives interleukin 22 production in intestinal NKp46+ cells that provide innate mucosal immune defense. Immunity 2008, 29:958-970.

19. Shiomi H, Masuda A, Nishiumi S, Nishida M, Takagawa T, Shiomi Y, Kutsumi H, Blumberg RS, Azuma T, Yoshida M: Gamma interferon produced by antigen-specific CD4+ T cells regulates the mucosal immune responses to Citrobacter rodentium infection. Infect Immun 2010, 78:2653-2666.

20. Jabri B, Ebert E: Human CD8+ intraepithelial lymphocytes: a unique model to study the regulation of effector cytotoxic T lymphocytes in tissue. Immunol Rev 2007, 215:202-214.

21. Beagley KW, Husband AJ: Intraepithelial lymphocytes: origins, distribution, and function. Crit Rev Immunol 1998, 18:237-254.

22. Sanz Y, De Palma G: Gut microbiota and probiotics in modulation of epithelium and gut-associated lymphoid tissue function. Int Rev Immunol 2009, 28:397-413.

23. Manicassamy S, Reizis B, Ravindran R, Nakaya H, Salazar-Gonzalez RM, Wang YC, Pulendran B: Activation of beta-catenin in dendritic cells regulates immunity versus tolerance in the intestine. Science 2010, 329:849-853.

24. Kawai T, Akira S: The role of pattern-recognition receptors in innate immunity: update on Toll-like receptors. Nat Immunol 2010, 11:373-384.

25. Hemmi H, Takeuchi O, Kawai T, Kaisho T, Sato S, Sanjo H, Matsumoto M, Hoshino K, Wagner H, Takeda K, Akira S: A Toll-like receptor recognizes bacterial DNA. Nature 2000, 408:740-745.

26. Kang JY, Nan X, Jin MS, Youn SJ, Ryu YH, Mah S, Han SH, Lee H, Paik SG, Lee JO: Recognition of lipopeptide patterns by Toll-like receptor 2-Tolllike receptor 6 heterodimer. Immunity 2009, 31:873-884.

27. Hugot JP, Chamaillard M, Zouali H, Lesage S, Cezard JP, Belaiche J, Almer S, Tysk C, O'Morain CA, Gassull M, Binder V, Finkel Y, Cortot A, Modigliani R, Laurent-Puig P, Gower-Rousseau C, Macry J, Colombel JF, Sahbatou M, Thomas G: Association of NOD2 leucine-rich repeat variants with susceptibility to Crohn's disease. Nature 2001, 411:599-603.

28. Keshet $Y$, Seger R: The MAP kinase signaling cascades: a system of hundreds of components regulates a diverse array of physiological functions. Methods Mol Biol 2010, 661:3-38.

29. Malladi V, Puthenedam M, Williams PH, Balakrishnan A: Enteropathogenic Escherichia coli outer membrane proteins induce iNOS by activation of NF-kappaB and MAP kinases. Inflammation 2004, 28:345-353.

30. Shames SR, Auweter SD, Finlay BB: Co-evolution and exploitation of hos cell signaling pathways by bacterial pathogens. Int J Biochem Cell Biol 2009, 41:380-389.

31. Sasakawa C: A new paradigm of bacteria-gut interplay brought through the study of Shigella. Proc Jpn Acad Ser B Phys Biol Sci 2010, 86:229-243.

32. Kim M, Ashida H, Ogawa M, Yoshikawa Y, Mimuro H, Sasakawa C: Bacterial interactions with the host epithelium. Cell Host Microbe 2010, 8:20-35.

33. Macdonald T, Monteleone G: Immunity, inflammation, and allergy in the gut. Science 2005, 307:1920-1925.

34. Iwai H, Kim M, Yoshikawa Y, Ashida H, Ogawa M, Fujita Y, Muller D, Kirikae T, Jackson PK, Kotani S, Sasakawa C: A bacterial effector targets Mad2L2, an APC inhibitor, to modulate host cell cycling. Cell 2007, 130:611-623.

35. Kim M, Ogawa M, Fujita Y, Yoshikawa Y, Nagai T, Koyama T, Nagai S, Lange A, Fassler R, Sasakawa C: Bacteria hijack integrin-linked kinase to stabilize focal adhesions and block cell detachment. Nature 2009, 459:578-582.

36. Tobe T, Beatson SA, Taniguchi H, Abe H, Bailey CM, Fivian A, Younis R, Matthews S, Marches O, Frankel G, Hayashi T, Pallen MJ: An extensive repertoire of type III secretion effectors in Escherichia coli 0157 and the role of lambdoid phages in their dissemination. Proc Natl Acad Sci USA 2006, 103:14941-14946.

37. Muenzner P, Bachmann V, Zimmermann W, Hentschel J, Hauck CR: Humanrestricted bacterial pathogens block shedding of epithelial cells by stimulating integrin activation. Science 2010, 329:1197-1201.

38. Marches O, Ledger TN, Boury M, Ohara M, Tu X, Goffaux F, Mainil J, Rosenshine I, Sugai M, De Rycke J, Oswald E: Enteropathogenic and enterohaemorrhagic Escherichia coli deliver a novel effector called Cif, which blocks cell cycle G2/M transition. Mol Microbiol 2003, 50:1553-1567. 
39. Jubelin G, Taieb F, Duda DM, Hsu Y, Samba-Louaka A, Nobe R, Penary M, Watrin C, Nougayrede JP, Schulman BA, Stebbins CE, Oswald E: Pathogenic bacteria target NEDD8-conjugated cullins to hijack host-cell signaling pathways. PLOS Pathog 2010, 6.

40. Samba-Louaka A, Nougayrede JP, Watrin C, Jubelin G, Oswald E, Taieb F: Bacterial cyclomodulin Cif blocks the host cell cycle by stabilizing the cyclin-dependent kinase inhibitors p21 and p27. Cell Microbiol 2008, 10:2496-2508.

41. Shames SR, Deng W, Guttman JA, de Hoog CL, Li Y, Hardwidge PR, Sham HP, Vallance BA, Foster LJ, Finlay BB: The pathogenic E. coli type III effector EspZ interacts with host CD98 and facilitates host cell prosurvival signalling. Cell Microbiol 2010, 12:1322-1339.

42. Hemrajani C, Berger CN, Robinson KS, Marches O, Mousnier A, Frankel G: NleH effectors interact with Bax inhibitor-1 to block apoptosis during enteropathogenic Escherichia coli infection. Proc Natl Acad Sci USA 2010, 107:3129-3134.

43. Baruch K, Gur-Arie L, Nadler C, Koby S, Yerushalmi G, Ben-Neriah Y, Yogev O, Shaulian E, Guttman C, Zarivach R, Rosenshine I: Metalloprotease type III effectors that specifically cleave JNK and NF-kappaB. Embo J 2010, 30:221-231.

44. Deng W, Puente JL, Gruenheid S, Li Y, Vallance BA, Vazquez A, Barba J, Ibarra JA, O'Donnell P, Metalnikov P, Ashman K, Lee S, Goode D, Pawson T, Finlay BB: Dissecting virulence: systematic and functional analyses of a pathogenicity island. Proc Natl Acad Sci USA 2004, 101:3597-3602.

45. Kelly M, Hart E, Mundy R, Marches O, Wiles S, Badea L, Luck S, Tauschek M, Frankel G, Robins-Browne RM, Hartland EL: Essential role of the type III secretion system effector NleB in colonization of mice by Citrobacter rodentium. Infect Immun 2006, 74:2328-2337.

46. Marches O, Wiles S, Dziva F, La Ragione RM, Schuller S, Best A, Phillips AD, Hartland EL, Woodward MJ, Stevens MP, Frankel G: Characterization of two non-locus of enterocyte effacement-encoded type III-translocated effectors, NleC and NleD, in attaching and effacing pathogens. Infect Immun 2005, 73:8411-8417.

47. Bhavsar AP, Guttman JA, Finlay BB: Manipulation of host-cell pathways by bacterial pathogens. Nature 2007, 449:827-834.

48. Petty NK, Bulgin R, Crepin VF, Cerdeno-Tarraga AM, Schroeder GN, Quail MA, Lennard N, Corton C, Barron A, Clark L, Toribio AL, Parkhill J, Dougan G, Frankel G, Thomson NR: The Citrobacter rodentium genome sequence reveals convergent evolution with human pathogenic Escherichia coli. J Bacteriol 2010, 192:525-538.

49. Garmendia J, Frankel G, Crepin VF: Enteropathogenic and enterohemorrhagic Escherichia coli infections: translocation, translocation, translocation. Infect Immun 2005, 73:2573-2585.

50. Czerucka D, Dahan S, Mograbi B, Rossi B, Rampal P: Implication of mitogen-activated protein kinases in T84 cell responses to enteropathogenic Escherichia coli infection. Infect Immun 2001, 69:1298-1305

51. Ramirez K, Huerta R, Oswald E, Garcia-Tovar C, Hernandez JM, NavarroGarcia F: Role of EspA and intimin in expression of proinflammatory cytokines from enterocytes and lymphocytes by rabbit enteropathogenic Escherichia coli-infected rabbits. Infect Immun 2005, 73:103-113.

52. Ruchaud-Sparagano MH, Maresca M, Kenny B: Enteropathogenic Escherichia coli (EPEC) inactivate innate immune responses prior to compromising epithelial barrier function. Cell Microbiol 2007, 9:1909-1921.

53. Sharma R, Tesfay S, Tomson FL, Kanteti RP, Viswanathan VK, Hecht G: Balance of bacterial pro- and anti-inflammatory mediators dictates net effect of enteropathogenic Escherichia coli on intestinal epithelial cells. Am J Physiol Gastrointest Liver Physiol 2006, 290:G685-694.

54. Mumy KL, McCormick BA: The role of neutrophils in the event of intestinal inflammation. Curr Opin Pharmacol 2009, 9:697-701.

55. Gao X, Wan F, Mateo K, Callegari E, Wang D, Deng W, Puente J, Li F, Chaussee MS, Finlay BB, Lenardo MJ, Hardwidge PR: Bacterial effector binding to ribosomal protein s3 subverts NF-kappaB function. PLoS Pathog 2009, 5:e1000708.

56. Wan F, Anderson DE, Barnitz RA, Snow A, Bidere N, Zheng L, Hegde V, Lam LT, Staudt LM, Levens D, Deutsch WA, Lenardo MJ: Ribosomal protein S3: a KH domain subunit in NF-kappaB complexes that mediates selective gene regulation. Cell 2007, 131:927-939.

57. Kim DW, Lenzen G, Page AL, Legrain P, Sansonetti PJ, Parsot C: The Shigella flexneri effector OspG interferes with innate immune responses by targeting ubiquitin-conjugating enzymes. Proc Natl Acad Sci USA 2005, 102:14046-14051.

58. Royan SV, Jones RM, Koutsouris A, Roxas JL, Falzari K, Weflen AW, Kim A, Bellmeyer A, Turner JR, Neish AS, Rhee KJ, Viswanathan VK, Hecht GA: Enteropathogenic E. coli non-LEE encoded effectors NleH1 and NleH2 attenuate NF-kappaB activation. Mol Microbiol 2010, 78:1232-1245.

59. Iguchi A, Thomson NR, Ogura Y, Saunders D, Ooka T, Henderson IR, Harris D, Asadulghani M, Kurokawa K, Dean P, Kenny B, Quail MA, Thurston S, Dougan G, Hayashi T, Parkhill J, Frankel G: Complete genome sequence and comparative genome analysis of enteropathogenic Escherichia coli 0127:H6 strain E2348/69. J Bacteriol 2009, 191:347-354.

60. Wickham ME, Lupp C, Mascarenhas M, Vazquez A, Coombes BK, Brown NF Coburn BA, Deng W, Puente JL, Karmali MA, Finlay BB: Bacterial genetic determinants of non-0157 STEC outbreaks and hemolytic-uremic syndrome after infection. J Infect Dis 2006, 194:819-827.

61. Newton HJ, Pearson JS, Badea L, Kelly M, Lucas M, Holloway G, Wagstaff KM, Dunstone MA, Sloan J, Whisstock JC, Kaper JB, RobinsBrowne RM, Jans DA, Frankel G, Phillips AD, Coulson BS, Hartland EL: The type III effectors NleE and NleB from enteropathogenic E. coli and OspZ from Shigella block nuclear translocation of NF-kappaB p65. PLoS Pathog 2010, 6:e1000898.

62. Muhlen S, Ruchaud-Sparagano MH, Kenny B: Proteasome-independent Degradation of Canonical NF\{kappa\}B Complex Components by the NleC Protein of Pathogenic Escherichia coli. J Biol Chem 2010, 286:5100-5107.

63. Pearson JS, Riedmaier P, Marches O, Frankel G, Hartland EL: A type III effector protease NleC from enteropathogenic Escherichia coli targets NF-kappaB for degradation. Mol Microbiol 2010.

64. Yen H, Ooka T, Iguchi A, Hayashi T, Sugimoto N, Tobe T: NleC, a type III secretion protease, compromises NF-kappaB activation by targeting p65/RelA. PLoS Pathog 2010, 6:e1001231.

65. Zurawski DV, Mumy KL, Badea L, Prentice JA, Hartland EL, McCormick BA, Maurelli AT: The NleE/OspZ family of effector proteins is required for polymorphonuclear transepithelial migration, a characteristic shared by enteropathogenic Escherichia coli and Shigella flexneri infections. Infect Immun 2008, 76:369-379.

66. Wickham ME, Lupp C, Vazquez A, Mascarenhas M, Coburn B, Coombes BK, Karmali MA, Puente $J$, Deng W, Finlay BB: Citrobacter rodentium virulence in mice associates with bacterial load and the type III effector NleE. Microbes Infect 2007, 9:400-407.

67. Deng W, de Hoog CL, Yu HB, Li Y, Croxen MA, Thomas NA, Puente JL, Foster $L$, Finlay BB: A comprehensive proteomic analysis of the type III secretome of Citrobacter rodentium. J Biol Chem 2010, 285:6790-6800.

68. Nadler C, Baruch K, Kobi S, Mills E, Haviv G, Farago M, Alkalay I, Bartfeld S, Meyer TF, Ben-Neriah Y, Rosenshine I: The type III secretion effector NleE inhibits NF-kappaB activation. PLoS Pathog 2010, 6:e1000743.

69. Vossenkamper A, Marches O, Fairclough PD, Warnes G, Stagg AJ, Lindsay JO, Evans PC, Luong le A, Croft NM, Naik S, Frankel G, MacDonald TT: Inhibition of NF-kappaB signaling in human dendritic cells by the enteropathogenic Escherichia coli effector protein NleE. $J$ Immunol 2010, 185:4118-4127.

70. Fitzhenry RJ, Reece S, Trabulsi LR, Heuschkel R, Murch S, Thomson M, Frankel G, Phillips AD: Tissue tropism of enteropathogenic Escherichia coli strains belonging to the $\mathrm{O} 55$ serogroup. Infect Immun 2002, 70:4362-4368.

71. Caron E, Hall A: Identification of two distinct mechanisms of phagocytosis controlled by different Rho GTPases. Science 1998 282:1717-1721

72. Celli J, Olivier M, Finlay BB: Enteropathogenic Escherichia coli mediates antiphagocytosis through the inhibition of PI 3-kinase-dependent pathways. EMBO J 2001, 20:1245-1258.

73. Dong N, Liu L, Shao F: A bacterial effector targets host $\mathrm{DH}-\mathrm{PH}$ domain RhoGEFs and antagonizes macrophage phagocytosis. EMBO J 2010, 29:1363-1376.

74. lizumi $Y$, Sagara H, Kabe $Y$, Azuma M, Kume K, Ogawa M, Nagai T, Gillespie PG, Sasakawa C, Handa H: The enteropathogenic E. coli effector EspB facilitates microvillus effacing and antiphagocytosis by inhibiting myosin function. Cell Host Microbe 2007, 2:383-392.

75. Marches O, Covarelli V, Dahan S, Cougoule C, Bhatta P, Frankel G, Caron E: EspJ of enteropathogenic and enterohaemorrhagic Escherichia coli inhibits opsono-phagocytosis. Cell Microbiol 2008, 10:1104-1115. 
76. Martinez-Argudo I, Sands C, Jepson MA: Translocation of enteropathogenic Escherichia coli across an in vitro $\mathrm{M}$ cell model is regulated by its type III secretion system. Cell Microbiol 2007, 9:1538-1546.

77. Quitard S, Dean P, Maresca M, Kenny B: The enteropathogenic Escherichia coli EspF effector molecule inhibits PI-3 kinase-mediated uptake independently of mitochondrial targeting. Cell Microbiol 2006, 8:972-981.

78. Holmes A, Muhlen S, Roe AJ, Dean P: The EspF effector, a bacterial pathogen's Swiss army knife. Infect Immun 2010, 78:4445-4453.

79. Weflen AW, Alto NM, Viswanathan VK, Hecht G: E. coli secreted protein F promotes EPEC invasion of intestinal epithelial cells via an SNX9dependent mechanism. Cell Microbiol 2010, 12:919-929.

80. Selyunin AS, Sutton SE, Weigele BA, Reddick LE, Orchard RC, Bresson SM, Tomchick DR, Alto NM: The assembly of a GTPase-kinase signalling complex by a bacterial catalytic scaffold. Nature 2011, 469:107-111.

81. Niedergang F, Colucci-Guyon E, Dubois T, Raposo G, Chavrier P: ADP ribosylation factor 6 is activated and controls membrane delivery during phagocytosis in macrophages. J Cell Biol 2003, 161:1143-1150.

82. Maddocks OD, Short AJ, Donnenberg MS, Bader S, Harrison DJ: Attaching and effacing Escherichia coli downregulate DNA mismatch repair protein in vitro and are associated with colorectal adenocarcinomas in humans. PLoS One 2009, 4:e5517.

83. Spehlmann ME, Dann SM, Hruz P, Hanson E, McCole DF, Eckmann L: CXCR2-dependent mucosal neutrophil influx protects against colitisassociated diarrhea caused by an attaching/effacing lesion-forming bacterial pathogen. I Immunol 2009, 183:3332-3343.

doi:10.1186/1476-9255-8-11

Cite this article as: Vossenkämper et al:: Always one step ahead: How pathogenic bacteria use the type III secretion system to manipulate the intestinal mucosal immune system. Journal of Inflammation 2011 8:11.

\section{Submit your next manuscript to BioMed Central and take full advantage of:}

- Convenient online submission

- Thorough peer review

- No space constraints or color figure charges

- Immediate publication on acceptance

- Inclusion in PubMed, CAS, Scopus and Google Scholar

- Research which is freely available for redistribution

Submit your manuscript at www.biomedcentral.com/submit 